Wilson's Disease

by I. HERBERT SCHEINBERG and IRMIN STERNLIEB, 192

pp., Philadelphia, W.B. Saunders Co., 1983. $\$ 35.00$

This thin book is packed with facts about Wilson's disease. The authors are leading authorities on the subject, both in the number of patients seen and in their contributions to some of the important advances in understanding the pathophysiology. The chapters cover history; genetics; ceruloplasmin; pathogenesis; liver pathology and neuropathology; clinical aspects of liver, nervous system, and other organs; and practical chapters on diagnosis and treatment. The concluding chapter is a discussion of the risks to parenthood. Pregnant women with Wilson's disease have continued to take ceruloplasmin without observable adverse effects on their infants. The authors use examples from their own personal cases (more than 100) to make specific points throughout the book. However, this monograph is not parochial; rather, it draws heavily from a large literature to provide the reader with much enlighten. ment about this intriguing disease.

Some examples of gems to be gleaned from this work: although Wilson's disease may be asymptomatic for as long as 40 years, once symptoms appear; there may be progression to irreversible changes within a week or two; rapid diagnosis is therefore imperative (page 114). If neurologic disease is present, the absence of Kayser-Fleischer rings excludes the diagnosis (page 119). D-penicillamine should be taken when there is no food in the stomach (page 126). About $10 \%$ of patients with neurologic manifestations may become worse in the first weeks or months of penicillamine therapy (page 127). Penicillamine reactions can be managed while treatment is continued (page 134), and other forms of treatment are available if penicillamine is not tolerated (page 148). There are only five essential findings of diagnostic value: Kayser-Fleischer rings, low serum ceruloplasmin, increased hepatic copper concentration, increased excretion of copper, and low radiocopper incorporation into ceruloplasmin. The authors point out which of these to seek in different clinical expressions of the illness (page 116). Serum copper determination is not listed as a useful test even though many neurologists use it to exclude Wilson's disease, probably because the test is readily available. In the next edition, the authors should emphasize even more strongly that determination of serum copper adds no information beyond that provided by a serum ceruloplasmin determination. They do state clearly that the two tests needed in the presence of neurologic signs are the serum ceruloplasmin concentration and slit-lamp examination for Kayser-Fleischer rings. A normal ceruloplasmin level alone excludes all but $5 \%$ of affected patients, and the other $5 \%$ are detected by slit-lamp examination.

Another suggestion for a second edition: in discussing the treatment of intractable dystonia unimproved by penicillamine, one might mention that Shoulson et al (Adv Neurol 1983;37:239-46) found beneficial effects from high-dosage trihexyphenidyl in one patient.

Although Wilson's disease is rare (the worldwide prevalence is 30 per million), this metabolic disorder needs to be recognized by the neurologist because it is treatable. This book will surely enhance the reader's awareness of its intricacies, and will raise consideration of the diagnosis. The book should be on the shelf of all neurologists; it should also be read by them.

Stanley Fahn, MD

\section{A History of Neurophysiology in the Seventeenth and Eighteenth Centuries}

by MARY A.B. BRAZIER, 230 pp., ill., New York, Raven Press, 1984. $\$ 71.50$

Mary Brazier is the authority on the history of physiology of the nervous system. As Dr. Brazier states, she has extracted material that is germane to our present understanding of the nervous system from the wealth of material available about seventeenth and eighteenth century physiology. The history of neurophysiology in the nineteenth century is to appear in a compan ion volume at a later date. These books will then be the definitive work on the subject. Brazier's history complements Clarke and O'Malley's The Human Brain and Spinal Cord: A Historical Study Illustrated by Writings from Antiquity to the Twentieth Century (University of California, 1968). Clarke and O'Malley's work is, however, more of a reference source, with short sections from the writings of various authors. Brazier's work can actually be read with interest and enjoyment.

The present volume begins with an introduction to the age-old concepts of Aristotle that were later amplified by Galen. Late in the sixteenth and early seventeenth centuries, doctrines developed from experimentation began to replace ancient concepts. A mechanistic philosophy, developed by Descartes and others, was advanced, and was based on early studies of the anatomy of the nervous system. The latter resulted from the invention of the microscope by van Leeuwenhoek, as well as from the rise of an English school of anatomy and physiology. This occurred at $\mathrm{Ox}$ ford with Willis and Lower, but also included Glisson and Croone, who brought a new scientific approach to early neurophysiology. Philosophic and mathematic concepts of Locke and Newton resulted from the shift of emphasis from untested concepts to those developed by inductive logic and experimentation. These areas of seventeenth-century science are covered in a quite readable fashion in the first part of Brazier's study.

The second section of this book examines neurophysiology in the eighteenth century. A natural separation occurs in physiology at this time because of improvements in scientific techniques. The fact that the nervous system functions in many aspects through electricity was unknown until this time. The distinction between magnetism and electricity had not been made. This section deals with the development of electrophysiology. It is placed in the setting of works of the great teachers, such as Boerhaave and Haller; the doctrine of the vitalists, such as Whytt; and the influence of the Enlightenment, exemplified by Diderot. Spinal cord physiology first began in this century. The science of electrophysiology was born in the last decade of the eighteenth century, as a consequence of remarkable experiments of Galvani on "animal electricity."

Brazier has set the development of neurophysiology in the context of important events in philosophy, politics, art, and literature for each period. Her style of writing makes a complicated topic enjoyable reading. At the end of each chapter, there is a list of selected readings of each physiologist, along with another of important secondary sources. Over 100 illustrations make this volume attractive and enhance the text. Name and subject indexes allow one to delve further into any given topic or person. This volume is valuable for those interested in the history of neurology and, more particularly, as a source for in-depth material on any aspect of the history of neurophysiology. The price is a bit steep for most.

Lawrence C. McHenry, Jr, MD

\section{Correction}

In the January 1985 issue of Neurology, the authors of Pathology of Skeletal Muscle were incorrectly identified as the editors, and one of their names was misspelled. The book was written by Stirling Carpenter, M.D., and George Karpati, M.D. We apologize for the error. 


\section{Neurology}

\section{Correction}

Neurology 1985;35;624-624-b

DOI 10.1212/WNL.35.4.624-b

This information is current as of April 1, 1985

\section{Updated Information \& Services}

Permissions \& Licensing

Reprints including high resolution figures, can be found at: http://n.neurology.org/content/35/4/624.3.citation.full

Information about reproducing this article in parts (figures,tables) or in its entirety can be found online at: http://www.neurology.org/about/about_the_journal\#permi ssions

Information about ordering reprints can be found online: http://n.neurology.org/subscribers/advertise

Neurology ${ }^{\circledR}$ is the official journal of the American Academy of Neurology. Published continuously since 1951, it is now a weekly with 48 issues per year. Copyright $\left(\begin{array}{l}1985 \\ \text { by }\end{array}\right.$ Modern Medicine Publications, Inc.. All rights reserved. Print ISSN: 0028-3878. Online ISSN: $1526-632 X$.

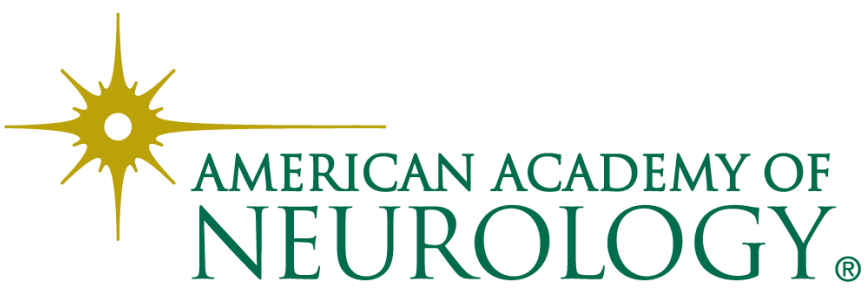

